\title{
Article
}

\section{Geochemical variation of the Late Cretaceous-Paleogene granitoids across the Ehime-Hiroshima-Shimane transect, Japan}

\author{
Shunso Ishihara ${ }^{1, *}$ and Tetsuji Ohno ${ }^{2}$
}

\begin{abstract}
Shunso Ishihara and Tetsuji Ohno (2016) Geochemical variation of the Late Cretaceous-Paleogene granitoids across the Ehime-Hiroshima-Shimane transect, Japan. Bull. Geol. Surv. Japan, vol. 67 (2), p. 41-58, 5 figs, 5 tables, 1 appendix.
\end{abstract}

\begin{abstract}
Geochemical and geomagnetic character of the Late Cretaceous-Paleogene granitic batholith was examined at N-S transect across the city of Hiroshima. The granitoids are mostly biotite granite in composition, but granodiorite predominates in the Takanawa Peninsula. Their magnetic susceptibility is the highest in the Sanin belt, but becomes lower of the ilmenite-series to the south and lowest in the southernmost Ryoke belt. The granitoids are most sodic in the Sanin belt and potassic in the Sanyo and Ryoke belts, which may reflect igneous and sedimentary source rocks, respectively. The alumina saturation index $(\mathrm{A} / \mathrm{CNK})$ is above 1.0, i.e., peraluminous, but never exceeding 1.1 for S-type granite. Rb and $\mathrm{Pb}$ replacing $\mathrm{K}$ are the least in the Sanin belt but the highest in the Ryoke and southern Sanyo belts. High-Sr granitoids and adakite of the northern Kyushu and the Kinki district were not found in the studied regions. Zircon saturation temperatures in the average of the studied granitoids are the highest of $753^{\circ} \mathrm{C}$ in the Ryoke belt, because granodiorite predominates here.
\end{abstract}

Keywords: Granitoids, magnetite-/ilmenite-series, petrochemistry

\section{Introduction}

Granitic rocks occur most widely in the Inner Zone of Southwest Japan. When their radiometric ages became available, the granitoids were found to have older, Late Cretaceous in age (95-75 Ma, K-Ar) in its southern parts of the Sanyo and Ryoke belts, and younger, Paleogene age (60-50 Ma, K-Ar) in the Sanin belt toward north (e.g., Kawano and Ueda, 1966). Recent U-Pb ages on zircon indicate also younging ages from 98-95 Ma in the Ryoke belt, 92-86 Ma in the Sanyo belt, and to 64-33 Ma in the Sanin belt, mainly on the Matsuyama-Hiroshima-Shimane transect (Tani et al., 2014). They were essentially different in the rock-forming oxide minerals; magnetite-bearing in the Sanin belt and magnetite-free in the Sanyo and Ryoke belts (Ishihara, 1971, 1979), and also on the contained mafic silicate minerals (Czamanske et al., 1981) and apatite (Ishihara and Moriyama, 2016).

These granitoids intrude into the late Paleozoic and Jurassic metamorphic and sedimentary rocks, and the Late Cretaceous volcanic-sedimentary rocks. Exposures of the granitoids are sporadic, no continuous outcrop from the Sanyo belt to the Sanin belt in general, but one at the Oasa township in the very northern of the Hiroshima Prefecture (Fig. 1). Therefore, the granitoid samples were collected there and dated by K-Ar method on the biotites, and found to have older than $80 \mathrm{Ma}$ toward south and 64 to $38 \mathrm{Ma}$ toward the north of Oasa township (Shibata and Ishihara, 1974), and cross-cut relationship was found at north of Oasa and studied by Higashimoto (1975).

Recently, U-Pb zircon age determination was performed on 92 granitoid samples across the eastern Chugoku District, about 120 $\mathrm{km}$ east of our studied region (Iida et al., 2015). They emphasized a stepwise decreasing on the measured ages northward from 95 to $30 \mathrm{Ma}$, with a distinct time gap between 60 and $48 \mathrm{Ma}$, although no intrusive relationship between each body has been observed. Besides the ages, regional variations of $\mathrm{Fe}_{2} \mathrm{O}_{3} / \mathrm{FeO}$ ratio (Ishihara, 1971), magnetic susceptibility (Ishihara, 1979), $\delta^{18} \mathrm{O}$ in quartz (Honma and Sakai, 1976) of the granitoids have been reported in the Chugoku District. There may be some other variations on the chemical compositions.

This paper intends to clarify the regional variations on

\footnotetext{
${ }^{1}$ AIST, Geological Survey of Japan, Research Institute of Geology and Geoinformation

${ }^{2}$ AIST, Geological Survey of Japan, Research Institute for Georesources and Environment

*Corresponding author: S.Ishihara,Central 7,1-1-1 Higashi, Tsukuba, Ibaraki 305-8567, Japan. Email: s-ishihara@aist.go.jp
} 
chemistry of these granitoids, and to consider the genetic background of these parameters. Locations of the analyzed samples are shown in Figure 1, and the sample locality and magnetic susceptibility data are described in Appendix 1.

\section{Geological background of the studied area}

The studied areas across the Late Cretaceous plutonic rocks of the western Shikoku and the Late Cretaceous to Paleogene ones of the central Chugoku districts are shown in Figure 1. The studied rocks are listed in Appendix 1, and their chemical compositions are given from south to north in Tables 1 to 5 . The rocks are mostly granitic in composition; mafic plutonic rocks occur very locally at the tip of the Takanawa Peninsula and in the Kitahiroshima-cho to the north of Hiroshima city.

\subsection{Ryoke belt granitoids}

The southernmost part of the studied granitoids are those in the Takanawa Peninsula, which are considered to belong mostly to the Ryoke metamorphic and plutonic rocks (Hirokawa, 1965; Okamura, 1967), except for biotite granites around the northern tip where occurring together metasomatic syenites (Murakami, 1959) and rare metal-bearing pegmatites (Minagawa et al., 1978, 2001; Sato et al., 2014), both of which are characteristic of the Sanyo belt granitoids (e.g., Aoki and Hida, 1974). The Ryoke granitoids were once classified as "older" and "younger" (Miyahisa and Hiraoka, 1970) without any radiometric age data.

The plutonic rocks are composed of magnetite-free rocks of tonalite and granodiorite mostly with some amounts of granites and then a little gabbroid (Ochi, 1982). They are mineralogically magnetite-free I-type granitoids, but garnet-bearing two mica granites are present very locally to the northwest in the Yanai district of Yamaguchi Prefecture. In the Takanawa Peninsula, the alumina-saturation index $(\mathrm{A} / \mathrm{CNK}$, Table 1$)$ is below the limit of $\mathrm{S}$ type of 1.1, thus I type. The magnetic susceptibilities as measured by Bison 3101 Model are very low, even on the low silica rocks (Appendix 1 and Table 1). Whole-rock $\delta^{18} \mathrm{O}$ ratios of these granitoids are high as 10 to $11 \%$ regardless of the silica contents, and initial $\mathrm{Sr}$ ratio is 0.70773 with an $\mathrm{Rb}-\mathrm{Sr}$ age of $92.6 \pm 3.8 \mathrm{Ma}$ (Honma et al., 1983).

Recent $\mathrm{U}-\mathrm{Pb}$ age dating on zircon indicates that the ages vary from $97.8 \pm 1.1 \mathrm{Ma}$ to $95.3 \pm 1.1 \mathrm{Ma}$ (Tani et al., 2014, and unpublished data), which are the oldest among the studied granitoids of the whole region. The granitoids are older than similar granitoids exposed to the east in Kagawa Prefecture of the same Shikoku Island. Eleven plutonic rocks were studied chemically including two gabbroids and one syenite (Table 1).

\subsection{Sanyo belt granitoids}

To the north, there occur granitoids of the Sanyo belt, which are also called as Kure Granite around Kure city (Higashimoto et al., 1985) and Hiroshima Granite around Hiroshima city. They are magnetite-free in the opaque minerals (i.e., ilmenite series) and are characterized by pink colored $\mathrm{K}$-feldspar. U-Pb ages of zircon are $92.1 \pm 0.8$ and $92.3 \pm 1.0 \mathrm{Ma}$ at Kure and Kurahashijima (Tani et al., 2014), where biotite granite mainly and lesser amount of granodiorite are exposed (Higashimoto et al., 1985). The central part of the Hiroshima Granite around Hiroshima and Kabe regions to the north have slightly younger in the zircon $\mathrm{U}-\mathrm{Pb}$ age of $87.3 \pm 0.9$ to $85.6 \pm 1.0 \mathrm{Ma}$ (Tani et al., 2014). The rock assemblage is similar but contains xenolithic mass of gabbroids (sample nos.73H72 and 73H89, Table 3).

The Hiroshima granites as a batholithic intrusion are composed of medium-grained hornblende-bearing biotite granite, mediumto coarse-grained biotite granite and fine-grained biotite granite, containing xenolithic gabbroids very locally. Oxygen isotopic ratios, $\delta^{18} \mathrm{O}$ values of quartz of the granitoids, decrease north from $13 \%$ at the Ryoke metamorphic belt, to $9 \%$ around the Kabe area (Honma and Sakai, 1976). Small pegmatites often occur in the Seto Inland Sea region, which can contain rare metal minerals (Sato et al., 2014), and productive amounts of Be-bearing minerals, such as phenacite hosted in the skarn body and danalite in the intruded alkaline granites at Mihara mine (Aoki and Hida, 1974).

Based on the sheet mapping results of 1:50,000 scale of Higashimoto et al. (1985), Takahashi et al. (1989) and Takahashi (1991), Takahashi (1993) emphasized in the Hiroshima city area that the main part is vertically zoned pluton, consisting of upper coarse-grained and lower medium-grained granites, although the $\mathrm{SiO}_{2}$ contents vary only from 76 to $71 \%$. The coarse-grained granite appear to be later than the medium-grained one, then fine-grained one is the youngest. These intrusive sequences have also been observed in the Kaitaichi Quadrangle (Takagi and Mizuno, 1999), although the age variation has not been given to the sequence. In the Daito-Yamasa region of the Sanin district, the marginal leucogranites gave older zircon ages of 65.3 and $64.2 \mathrm{Ma}$, while coarse-grained batholithic granite and granodiorite were dated at much younger ages of $59.7 \mathrm{Ma}$ and 56.6 Ma, respectively (Ishihara and Tani, 2013). Thus, similar age determination is necessary in the Hiroshima region.

Hayashi (1995) found in the Togouchi-Yuu-Takehara region that the Hiroshima Granite is not a uniform body but accumulated layered bodies. Relatively mafic granites as granodiorite or hornblende-bearing granite occur above tabular body of biotite granites. He concluded that the Hiroshima granite as a whole tabular body dipping gently southward, intruded into the Late Cretaceous volcanic rocks after the rhyolitic eruption of the 


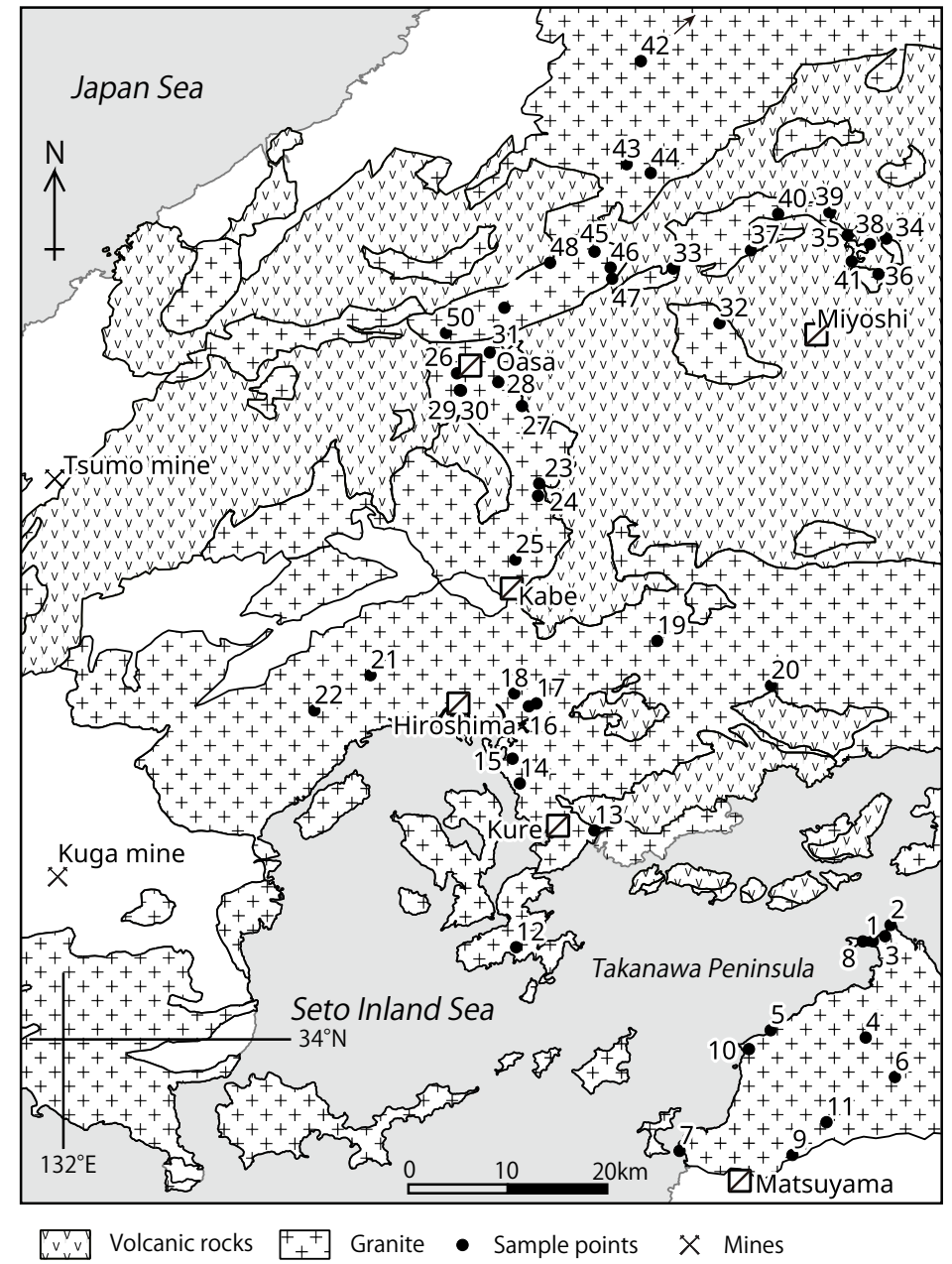

Fig. 1 Distribution of granitoids along the Hiroshima transect of central Chugoku District.

Takada Rhyolites.

To the north of Oasa township, similar granitoids are continuously exposed from the Sanyo belt (Hiroshima Pref.) to north of the Sanin belt (Shimane Pref.). Shibata and Ishihara (1974) determined the K-Ar ages on the biotites, and found the abrupt change from 80 to $38 \mathrm{Ma}$ at north of the Oasa township, which were recalculated later by the new decay constant as 82 and $39 \mathrm{Ma}$, respectively (Sato et al., 1992).

Higashimoto (1975) followed up the results and found that an E-W trending vertical boundary of the two granitoids at $700 \mathrm{~m}$ NE of Nobori community at northwest of Oasa township. Here, the southern coarse-grained granite, strictly monzogranite by his modal analyses, which belongs to the Hiroshima Granite with the Late Cretaceous age, was intruded by the northern apliticporphyritic granite, strictly syenogranite by modal analyses, of the Paleogene in age.

Rezanov et al. (1994) adopted a whole-rock Rb-Sr isochron dating method for the same area, and obtained $72.9 \pm 2.8 \mathrm{Ma}$ of the internal isochron age on the Oasa Granite, which was strangely younger than K-Ar biotite age of 80.2 $\pm 3.2 \mathrm{Ma}$ (Shibata and Ishihara, 1974). A further radiometric dating is needed.

To the east of Oasa, several small granitic bodies occur in Aki-takata city and Miyoshi city region, which give K-Ar biotite ages of $72 \mathrm{Ma}$ at Tokorogi on the Shikijiki Granite and $87 \mathrm{Ma}$ of Miyoshi region (Kawano and Ueda, 1966). Matsuura (1989) added K-Ar biotite age of $84.7 \pm 4.2$ Ma for the Shikijiki granite, and Rezanov et al. (1994) reported a whole rock isochron age of $80.5 \pm 3.9 \mathrm{Ma}$ for the same intrusive body.

To further northeast, Takagi et al. (1989) identified the Rb-Sr whole-rock-mineral isochron ages of $80.4 \pm 3.3$ and $83.4 \pm 4.4$ $\mathrm{Ma}$ on the two granitic stocks of Mitsumori and Ikuridani granites, which constitute the basement for Miocene U-bearing sediments (Ishihara et al., 1969). Takagi et al. (1989) considered the Mitsumori is typical magnetite-series while the Ikuridani is typical ilmenite-series granites. However, their data on the 
Table 1 Chemical compositions of plutonic rocks of the Ryoke belt: Takanawa Peninsula, Ehime Prefecture.

\begin{tabular}{|c|c|c|c|c|c|c|c|c|c|c|c|}
\hline Location & & yoke belt: & akanawa I & ninsula, El & me Prefct & & & & & & \\
\hline Filing no. & 1 & 2 & 3 & 4 & 5 & 6 & 7 & 8 & 9 & 10 & 11 \\
\hline Sample no. & 75 MY 10 & 75 MY 15 & 75 MY 14 & 75 MY 20 & 75 MY 6 & 75 MY 21 & 75 MY 4 & 75 MY 13 & 75 MY 2 & 75 MY 5 & 75 MY 1 \\
\hline $\mathrm{SiO}_{2}$ & 47.59 & 53.67 & 63.14 & 66.63 & 67.13 & 68.59 & 71.99 & 75.06 & 75.42 & 76.63 & 77.94 \\
\hline $\mathrm{TiO}_{2}$ & 0.32 & 1.23 & 0.22 & 0.59 & 0.64 & 0.47 & 0.26 & 0.09 & 0.20 & 0.09 & 0.07 \\
\hline $\mathrm{Al}_{2} \mathrm{O}_{3}$ & 19.83 & 16.37 & 18.41 & 15.65 & 15.54 & 14.14 & 14.03 & 12.86 & 13.01 & 12.75 & 12.56 \\
\hline $\mathrm{Fe}_{2} \mathrm{O}_{3}(\mathrm{~T})$ & 6.36 & 8.97 & 2.52 & 4.56 & 4.74 & 3.80 & 2.67 & 1.24 & 1.94 & 1.19 & 0.77 \\
\hline $\mathrm{MnO}$ & 0.12 & 0.16 & 0.08 & 0.08 & 0.08 & 0.08 & 0.06 & 0.03 & 0.06 & 0.02 & 0.03 \\
\hline $\mathrm{MgO}$ & 8.39 & 4.49 & 0.17 & 1.23 & 1.28 & 1.04 & 0.45 & 0.13 & 0.35 & 0.08 & 0.10 \\
\hline $\mathrm{CaO}$ & 14.30 & 8.61 & 3.26 & 4.05 & 4.52 & 3.38 & 2.01 & 1.24 & 1.62 & 0.75 & 0.94 \\
\hline $\mathrm{Na}_{2} \mathrm{O}$ & 0.96 & 2.09 & 3.75 & 3.11 & 3.22 & 3.33 & 3.08 & 2.96 & 3.29 & 3.01 & 2.87 \\
\hline $\mathrm{K}_{2} \mathrm{O}$ & 0.23 & 1.43 & 8.07 & 3.11 & 2.51 & 2.97 & 3.98 & 4.81 & 4.45 & 4.85 & 5.50 \\
\hline $\mathrm{P}_{2} \mathrm{O}_{5}$ & 0.05 & 0.17 & 0.05 & 0.16 & 0.14 & 0.14 & 0.06 & 0.03 & 0.07 & $<0.01$ & 0.03 \\
\hline S & 0.15 & 0.04 & 0.02 & 0.02 & 0.02 & 0.02 & 0.01 & 0.05 & 0.01 & 0.01 & 0.01 \\
\hline LOI & 1.20 & 1.46 & 0.28 & 0.76 & 0.73 & 0.87 & 0.94 & 0.63 & 0.50 & 0.72 & 0.18 \\
\hline Total & 99.35 & 98.66 & 99.96 & 99.94 & 100.50 & 98.81 & 99.53 & 99.08 & 100.90 & 100.10 & 101.00 \\
\hline $\mathrm{Rb}$ & $<10$ & 40 & 220 & 90 & 100 & 130 & 140 & 180 & 170 & 160 & 130 \\
\hline $\mathrm{Sr}$ & 321 & 287 & 649 & 254 & 276 & 207 & 149 & 90 & 112 & 67 & 53 \\
\hline $\mathrm{Ba}$ & 37 & 222 & 951 & 651 & 555 & 485 & 613 & 355 & 268 & 727 & 126 \\
\hline $\mathrm{Zr}$ & 18 & 128 & 172 & 170 & 151 & 135 & 112 & 81 & 93 & 111 & 70 \\
\hline $\mathrm{Hf}$ & 0.3 & 2.6 & 4 & 3.8 & 2.8 & 2.6 & 2.8 & 2.6 & 2.5 & 2.9 & 2.6 \\
\hline $\mathrm{Ta}$ & $<0.3$ & $<0.3$ & $<0.3$ & 1.3 & $<0.3$ & 1.2 & 1.4 & 1.3 & 1.2 & 0.9 & $<0.3$ \\
\hline $\mathrm{Y}$ & 6 & 26 & 24 & 38 & 19 & 24 & 23 & 28 & 18 & 16 & 10 \\
\hline $\mathrm{V}$ & 157 & 132 & 7 & 48 & 50 & 38 & 16 & 7 & 13 & $<5$ & $<5$ \\
\hline $\mathrm{Cr}$ & 454 & 109 & $<0.5$ & 12.6 & 11.2 & 6.8 & 1.4 & $<0.5$ & 2.7 & $<0.5$ & $<0.5$ \\
\hline Co & 35.3 & 25 & 2.8 & 8.4 & 8.2 & 6.7 & 4 & $<0.1$ & 2.3 & $<0.1$ & 1.4 \\
\hline $\mathrm{Ni}$ & 55 & 23 & 4 & 11 & 5 & 9 & 1 & 3 & 2 & 2 & 1 \\
\hline $\mathrm{Cu}$ & 58 & 23 & 5 & 3 & 3 & 3 & 4 & 27 & 2 & 2 & 1 \\
\hline $\mathrm{Zn}$ & 34 & 82 & 62 & 69 & 71 & 53 & 56 & 41 & 45 & 38 & 15 \\
\hline $\mathrm{Pb}$ & $<5$ & 8 & 25 & 15 & 11 & 7 & 20 & 35 & 23 & 22 & 39 \\
\hline As & 6 & $<1$ & $<1$ & 2 & $<1$ & $<1$ & $<1$ & 19 & $<1$ & $<1$ & $<1$ \\
\hline Mo & $<2$ & $<2$ & 2 & $<2$ & $<2$ & $<2$ & 3 & 12 & $<2$ & $<2$ & $<2$ \\
\hline $\mathrm{W}$ & $<1$ & $<1$ & $<1$ & $<1$ & $<1$ & $<1$ & $<1$ & $<1$ & $<1$ & $<1$ & $<1$ \\
\hline $\mathrm{Sb}$ & 0.2 & 0.2 & $<0.1$ & 0.2 & $<0.1$ & 0.2 & $<0.1$ & 0.3 & 0.2 & 0.3 & 0.1 \\
\hline Cs & 1.2 & 2.8 & 2.7 & 3.1 & 3.2 & 4.7 & 5 & 3.4 & 8.6 & 4.1 & 3 \\
\hline Th & 0.5 & 5.4 & 16.6 & 15.6 & 11.5 & 14.1 & 20.7 & 19.1 & 17.5 & 19.1 & 31.9 \\
\hline $\mathrm{U}$ & $<0.1$ & 0.8 & 2.2 & 3.1 & 1.8 & 3.2 & 4.5 & 4.7 & 6 & 2.9 & 7 \\
\hline $\mathrm{Be}$ & $<1$ & 1 & 2 & 2 & 2 & 2 & 2 & 2 & 2 & 2 & 1 \\
\hline $\mathrm{Sc}$ & 35.4 & 33.7 & 6.32 & 11.9 & 9.47 & 9.28 & 7.36 & 2.66 & 3.48 & 4.21 & 1.46 \\
\hline $\mathrm{La}$ & 2.72 & 18.6 & 49.3 & 39.4 & 33.5 & 31 & 36 & 25.8 & 20 & 22.4 & 13.3 \\
\hline $\mathrm{Ce}$ & 6 & 40 & 89 & 74 & 59 & 55 & 64 & 48 & 39 & 31 & 27 \\
\hline $\mathrm{Nd}$ & $<1$ & 26 & 47 & 32 & 29 & 25 & 27 & 24 & 18 & 21 & 14 \\
\hline $\mathrm{Sm}$ & 0.97 & 5.28 & 7.94 & 6.97 & 4.87 & 4.63 & 5.06 & 4.75 & 3.39 & 3.99 & 2.55 \\
\hline $\mathrm{Eu}$ & 0.43 & 1.01 & 1.15 & 1.09 & 1.06 & 0.87 & 0.81 & 0.46 & 0.52 & 0.5 & 0.3 \\
\hline $\mathrm{Tb}$ & $<0.1$ & 0.7 & 0.7 & 1 & $<0.1$ & 0.6 & $<0.1$ & 0.7 & $<0.1$ & $<0.1$ & 0.6 \\
\hline $\mathrm{Yb}$ & 0.65 & 2.49 & 2.08 & 3.35 & 1.63 & 2.49 & 2.46 & 2.95 & 2.21 & 1.88 & 1.31 \\
\hline $\mathrm{Lu}$ & 0.09 & 0.38 & 0.32 & 0.5 & 0.27 & 0.38 & 0.41 & 0.48 & 0.39 & 0.31 & 0.21 \\
\hline $\mathrm{A} / \mathrm{CNK}$ & 0.71 & 0.79 & 0.88 & 0.99 & 0.96 & 0.95 & 1.08 & 1.04 & 0.99 & 1.10 & 1.01 \\
\hline $\mathrm{ZrT}\left({ }^{\circ} \mathrm{C}\right)$ & 545 & 707 & 752 & 778 & 765 & 759 & 760 & 734 & 739 & 766 & 721 \\
\hline
\end{tabular}


Geochemical variation of the Ryoke, Sanyo and Sanin granitoids (Ishihara and Ohno)

Table 2 Chemical compositions of plutonic rocks of the Sanyo belt: Hiroshima city south, Hiroshima Prefecture.

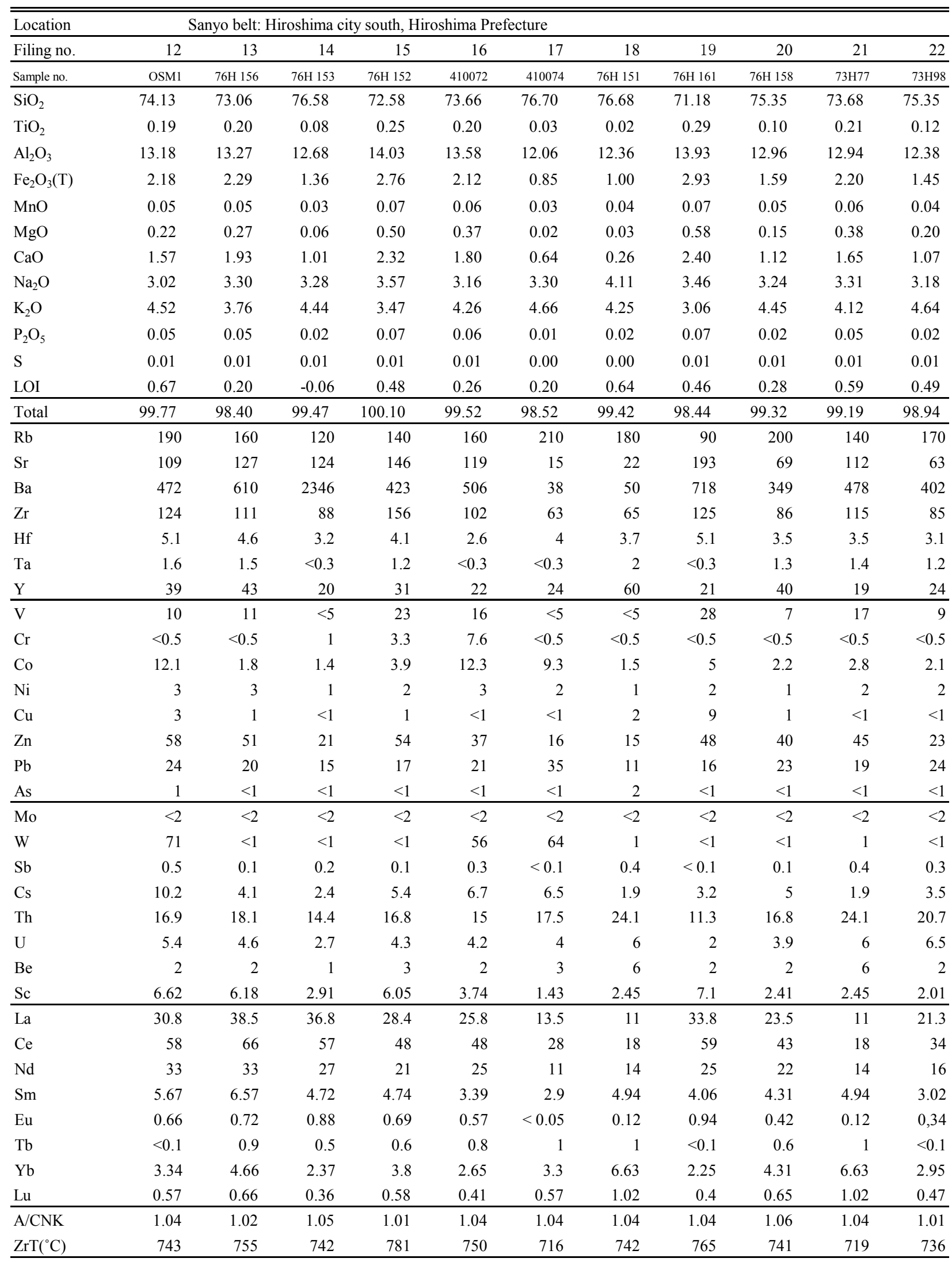

High values of $\mathrm{W}$ and $\mathrm{Co}$ on the 16 an 17 samples are due to crushing device. 
Table 3 Chemical compositions of plutonic rocks of the Sanyo belt: Hiroshima city north, Hiroshima Prefecture.

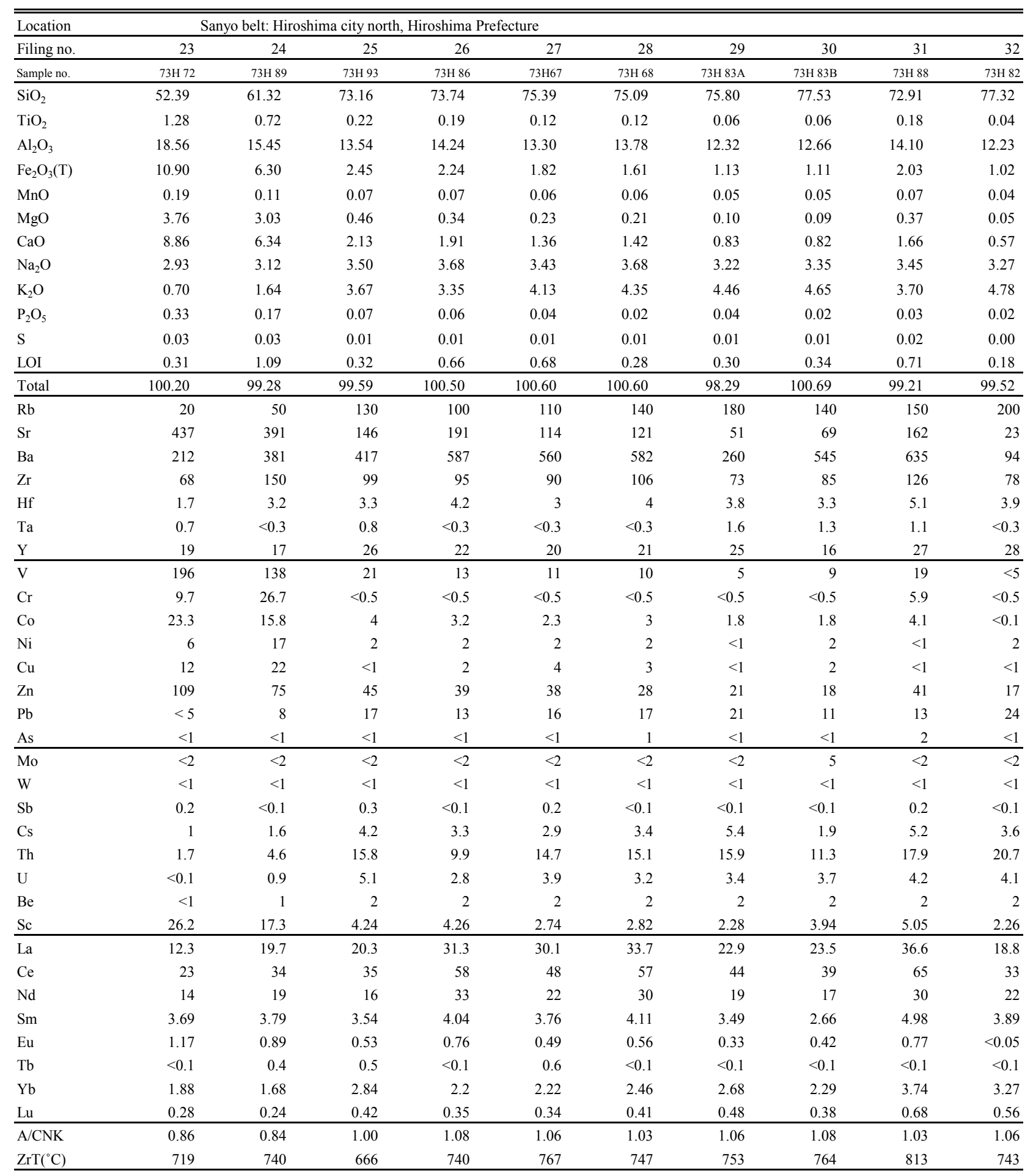


Geochemical variation of the Ryoke, Sanyo and Sanin granitoids (Ishihara and Ohno)

Table 4 Chemical compositions of plutonic rocks of the Miyoshi-Shobara cities, Hiroshima Prefecture.

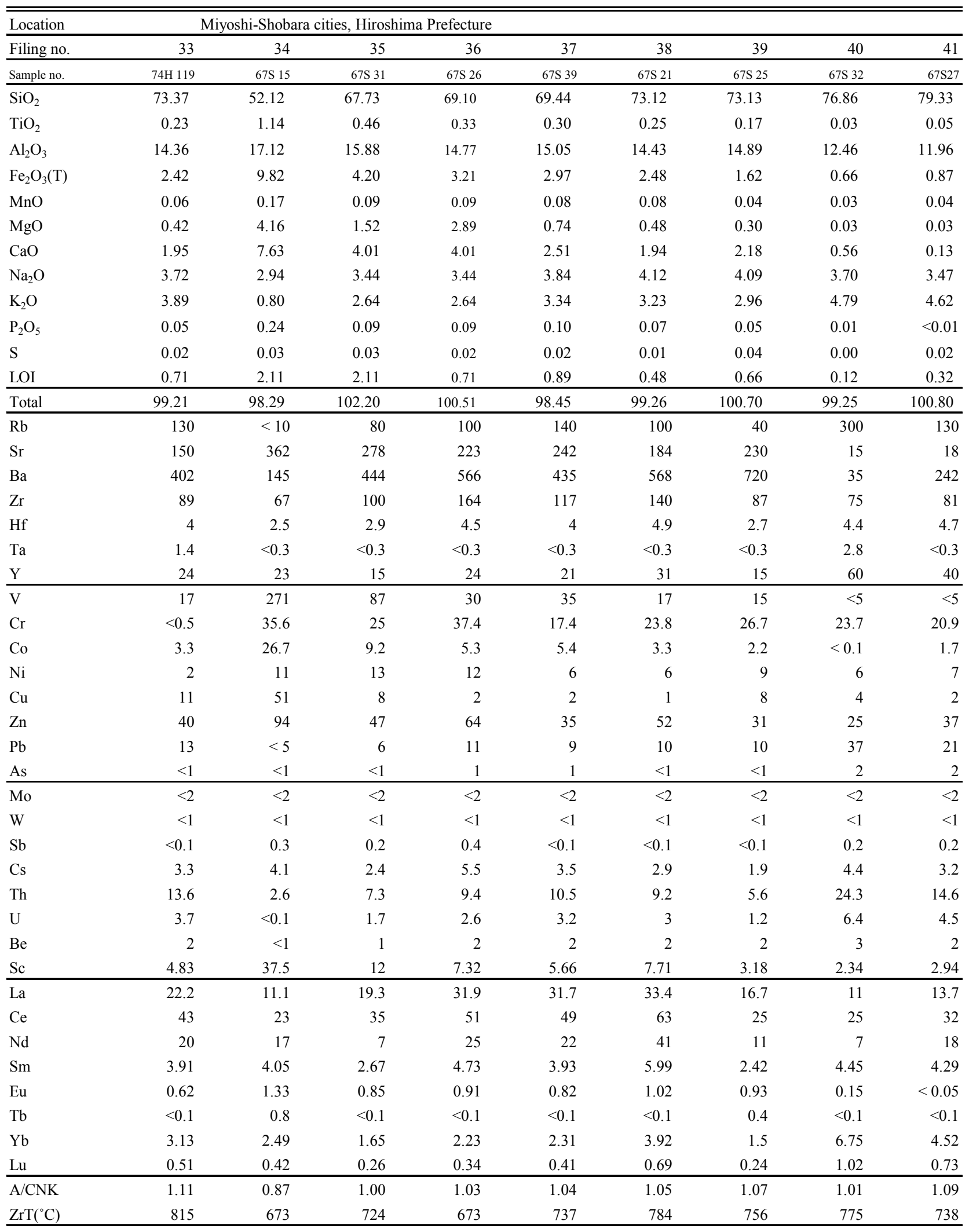


Table 5 Chemical compositions of plutonic rocks of the Sanin belt: Southern Shimane Prefecture.

\begin{tabular}{|c|c|c|c|c|c|c|c|c|c|}
\hline Location & & belt: Sou & Shimane & cture & & & & & \\
\hline Filing no. & 42 & 43 & 44 & 45 & 46 & 47 & 48 & 49 & 50 \\
\hline Sample no. & $73 \mathrm{H} 51$ & $73 \mathrm{H} 60$ & $73 \mathrm{H} 61$ & $73 \mathrm{H} 64$ & $73 \mathrm{H} 63$ & $73 \mathrm{H} 62$ & $73 \mathrm{H} 65$ & $73 \mathrm{H} 87$ & $73 \mathrm{H} 66$ \\
\hline $\mathrm{SiO}_{2}$ & 70.67 & 70.92 & 71.59 & 75.25 & 75.55 & 75.92 & 76.69 & 76.91 & 77.23 \\
\hline $\mathrm{TiO}_{2}$ & 0.41 & 0.49 & 0.38 & 0.12 & 0.19 & 0.16 & 0.13 & 0.16 & 0.16 \\
\hline $\mathrm{Al}_{2} \mathrm{O}_{3}$ & 14.74 & 14.82 & 13.68 & 12.78 & 13.13 & 12.28 & 12.60 & 12.72 & 12.82 \\
\hline $\mathrm{Fe}_{2} \mathrm{O}_{3}(\mathrm{~T})$ & 2.99 & 3.00 & 2.45 & 1.52 & 0.95 & 1.17 & 1.63 & 0.99 & 1.03 \\
\hline $\mathrm{MnO}$ & 0.07 & 0.09 & 0.07 & 0.04 & 0.03 & 0.02 & 0.04 & 0.04 & 0.03 \\
\hline $\mathrm{MgO}$ & 1.13 & 0.68 & 0.62 & 0.13 & 0.31 & 0.22 & 0.18 & 0.18 & 0.21 \\
\hline $\mathrm{CaO}$ & 2.80 & 1.97 & 1.66 & 0.94 & 1.40 & 0.76 & 0.94 & 0.90 & 0.67 \\
\hline $\mathrm{Na}_{2} \mathrm{O}$ & 3.90 & 4.52 & 4.16 & 3.87 & 3.95 & 3.63 & 3.78 & 3.94 & 3.75 \\
\hline $\mathrm{K}_{2} \mathrm{O}$ & 3.09 & 2.99 & 3.25 & 3.74 & 3.09 & 3.97 & 3.88 & 3.67 & 4.16 \\
\hline $\mathrm{P}_{2} \mathrm{O}_{5}$ & 0.13 & 0.15 & 0.09 & 0.03 & 0.03 & 0.03 & 0.03 & 0.03 & 0.02 \\
\hline S & 0.02 & 0.01 & 0.01 & 0.01 & 0.01 & 0.01 & 0.01 & 0.01 & 0.01 \\
\hline LOI & 0.32 & 0.62 & 0.66 & 0.20 & 0.24 & 0.28 & 0.04 & 0.26 & 0.34 \\
\hline Total & 100.30 & 98.59 & 98.59 & 99.64 & 98.86 & 98.45 & 99.96 & 99.80 & 100.43 \\
\hline $\mathrm{Rb}$ & 90 & 110 & 90 & 140 & 70 & 110 & 120 & 120 & 190 \\
\hline $\mathrm{Sr}$ & 344 & 203 & 156 & 67 & 165 & 73 & 68 & 95 & 52 \\
\hline $\mathrm{Ba}$ & 547 & 447 & 465 & 568 & 550 & 523 & 601 & 516 & 267 \\
\hline $\mathrm{Zr}$ & 121 & 227 & 219 & 120 & 93 & 86 & 117 & 87 & 69 \\
\hline Hf & 3.7 & 7.8 & 8.3 & 5.1 & 3.9 & 3.2 & 5.7 & 3.2 & 3.6 \\
\hline $\mathrm{Ta}$ & $<0.3$ & 1.8 & $<0.3$ & $<0.3$ & $<0.3$ & $<0.3$ & 1.2 & 1.8 & 1.3 \\
\hline $\mathrm{Y}$ & 13 & 31 & 29 & 32 & 11 & 15 & 35 & 14 & 25 \\
\hline V & 54 & 37 & 28 & 7 & 12 & 10 & 7 & 9 & 6 \\
\hline $\mathrm{Cr}$ & 11.3 & $<0.5$ & $<0.5$ & $<0.5$ & $<0.5$ & $<0.5$ & $<0.5$ & $<0.5$ & 5.5 \\
\hline Co & 6.4 & 4.1 & 3.4 & 2.4 & 2.7 & 1.4 & 1.8 & 2.4 & 1.3 \\
\hline $\mathrm{Ni}$ & 7 & 3 & 10 & 1 & 2 & 1 & 1 & 2 & 2 \\
\hline $\mathrm{Cu}$ & 4 & 6 & 20 & 2 & 6 & 13 & 2 & 4 & 1 \\
\hline $\mathrm{Zn}$ & 39 & 41 & 48 & 32 & 16 & 16 & 36 & 24 & 22 \\
\hline $\mathrm{Pb}$ & 11 & 9 & 14 & 12 & 10 & 11 & 12 & 18 & 21 \\
\hline As & $<1$ & $<1$ & $<1$ & 3 & $<1$ & $<1$ & $<1$ & 2 & $<1$ \\
\hline Mo & $<2$ & $<2$ & $<2$ & $<2$ & $<2$ & $<2$ & $<2$ & $<2$ & $<2$ \\
\hline W & $<1$ & $<1$ & $<1$ & $<1$ & $<1$ & $<1$ & $<1$ & $<1$ & $<1$ \\
\hline $\mathrm{Sb}$ & $<0.1$ & 0.2 & $<0.1$ & 0.2 & $<0.1$ & $<0.1$ & 0.3 & 0.3 & 0.3 \\
\hline Cs & 3 & 2.3 & 2.9 & 3 & 0.8 & 1.9 & 3.3 & 2.3 & 4.9 \\
\hline Th & 9.1 & 8.6 & 8.7 & 14.6 & 8.5 & 10.4 & 14.2 & 10.1 & 14.6 \\
\hline $\mathrm{U}$ & 2.1 & 3 & 2.5 & 4 & 2.1 & 2.6 & 3.4 & 3 & 4.4 \\
\hline $\mathrm{Be}$ & 1 & 2 & 2 & 2 & 1 & 2 & 2 & 2 & 2 \\
\hline$\underline{\mathrm{Sc}}$ & 6.44 & 8.41 & 6.46 & 8.12 & 3.11 & 3.99 & 8.21 & 3.67 & 2.18 \\
\hline $\mathrm{La}$ & 25.3 & 26.4 & 25.6 & 30.9 & 22.3 & 21.9 & 37.2 & 21.6 & 22.8 \\
\hline $\mathrm{Ce}$ & 46 & 53 & 50 & 62 & 35 & 40 & 68 & 37 & 40 \\
\hline $\mathrm{Nd}$ & 17 & 27 & 24 & 30 & 16 & 16 & 33 & 11 & 16 \\
\hline $\mathrm{Sm}$ & 2.97 & 5.35 & 4.9 & 5.85 & 2.03 & 2.52 & 6.11 & 2.44 & 3.33 \\
\hline $\mathrm{Eu}$ & 0.76 & 1.31 & 1.01 & 0.74 & 0.48 & 0.3 & 0.79 & 0.42 & 0.31 \\
\hline $\mathrm{Tb}$ & $<0.1$ & 0.9 & $<0.1$ & $<0.1$ & $<0.1$ & $<0.1$ & $<0.1$ & $<0.1$ & 1 \\
\hline $\mathrm{Yb}$ & 1.37 & 3.75 & 3.76 & 4.91 & 1.31 & 1.99 & 3.86 & 1.94 & 2.79 \\
\hline$\underline{\mathrm{Lu}}$ & 0.27 & 0.64 & 0.7 & 0.81 & 0.23 & 0.35 & 0.68 & 0.36 & 0.49 \\
\hline $\mathrm{A} / \mathrm{CNK}$ & 0.99 & 1.04 & 1.02 & 1.05 & 1.06 & 1.05 & 1.04 & 1.05 & 1.05 \\
\hline $\operatorname{ZrT}\left({ }^{\circ} \mathrm{C}\right)$ & 726 & 741 & 755 & 745 & 765 & 767 & 746 & 741 & 741 \\
\hline
\end{tabular}


magnetic susceptibility in Figure 3 indicate that the Ikuridani ilmenite-series granite has validity, but the Mitsumori granite has roughly $50 \%$ of magnetite-free values, not typical magnetiteseries.

Their age is also not Paleogene but Late Cretaceous. K-Ar age on biotite of the Mitsumori Granite revealed a Late Cretaceous in age of $81.8 \pm 4.1 \mathrm{Ma}$ (Matsuura, 1998), and the zircon U-Pb age is slightly older but still in the Late Cretaceous age of $86.2 \pm 0.7$ $\mathrm{Ma}$ (Tani et al., 2014). Thus it is considered to belong to a part of Sanyo belt granitic activities in this paper.

\subsection{Sanin belt granitoids}

The Sanin belt granitoids of Paleogene age are classified into three groups, as (i) early, (ii) middle and (iii) late intrusive rocks in the Akana Quadrangle Series by Matsuura (1990). The main Paleogene granitoids, elongating ENE direction by a size of 8 and $29 \mathrm{~km}$ at ENE of the Oasa township area, are called Asuna Granites, and are divided into the marginal granophyre and the central granite porphyry by Rezanov et al. (1994). They give the internal isochron ages of $40.4 \pm 2.9 \mathrm{Ma}$ and $28.9 \pm 5.8 \mathrm{Ma}$, respectively.

The age discrepancy is much larger than one can think of the cooling of the marginal to the main phases of the crystallization. The errors are also so large; thus further chronological study, especially on zircon, is definitely needed. One zircon dating in our study showed $39.8 \pm 0.6 \mathrm{Ma}$ at north of Akana (Tani et al., 2014). Besides, small dioritic bodies are associated with these biotite granites (Matsuura, 1990).

Along the Tottori-Okayama transect toward the east of our study area, the largest age gap was recognized at 40-60 Ma (Iida et al., 2015), which could separate the granitic activities of the Sanyo and Sanin belts.

\section{Result of analyses and discussion on the north-south chemical variation}

The studied rocks are listed in Appendix 1, and their chemical compositions are given from south to north in Tables 1 to 5 . Chemical analyses were carried out at Activation Laboratories Ltd. (Actlabs, Toronto, Canada) using Inductively Coupled Plasma Mass Spectrometry (ICP-MS). Magnetic susceptibilities were measured using Bison 3101 Model susceptibility meter (Bison Instruments Inc., Chanhassen, Minnesota, USA).

The studied rocks are mostly monzogranite in the feldspars and quartz ratios, except for the Takanawa Peninsula in the Ryoke belt where quartz diorite-granodiorite occurs an affair amount. The granitoids are extremely low in the magnetic susceptibility, $\chi$-values below $100 \times 10^{-6} \mathrm{Am}^{2} / \mathrm{kg}$, belonging to the ilmeniteseries, both in the Ryoke belt and the southernmost Sanyo belt. The magnetic susceptibility increases gradually toward the north, then, sporadic magnetite-series values appearing in the ilmenite-series granitic terrane in the northern Sanyo belt (Appendix 1).

Granitoids of the Sanyo belt around the Hiroshima city north region are mostly granitic in composition (see also Takahashi, 1993), and contains locally xenolithic gabbroids including quartz dioritic rocks in the limited places, whose magnetic susceptibility goes up to $731 \times 10^{-6} \mathrm{Am}^{2} / \mathrm{kg}$ (e.g., $73 \mathrm{H} 72$, Appendix 1); the values are still low as $1 / 5^{\text {th }}$ of that of typical magnetite-series gabbroids in the Zakka magnetite-placer mine area of the Sanin belt (see, Fig. 8 of Ishihara, 1979). The surrounding granites show the values of the ilmenite-series.

Chemical components of the studied rocks with $\mathrm{SiO}_{2}$ contents higher than $66 \%$ (granodiorite-granitic composition), are plotted against the silica contents, and are shown from south to north in Figures 2 to 5 . The most distinct character is seen in the alkali ratio. $\mathrm{Na}_{2} \mathrm{O}$ contents, for example, are least in those of the Ryoke belt and increase gradually toward north, then the highest in those of the Sanin belt (Fig. 2C). On the contrary, $\mathrm{K}_{2} \mathrm{O}$ contents are highest in those of the Ryoke belt and are least in those of the Sanin belt (Fig. 2D). $\mathrm{Na}_{2} \mathrm{O}$-rich character was also observed in granitoids of the Shirakawa region of the Chubu District (Ishihara and Tani, 2004), which is an eastern extension area of the Sanin belt.

$\mathrm{Na}_{2} \mathrm{O}$ is the main constituent of plagioclase, and also contained in some amounts of the $\mathrm{K}$-feldspar in igneous rocks. Therefore, $\mathrm{Na}_{2} \mathrm{O}$-rich magma must have originated in igneous source rocks containing plagioclase, while $\mathrm{K}_{2} \mathrm{O}$-rich granitoids of the Ryoke belt should be affected by sedimentary source rocks of mainly pelitic in composition. In the Japanese eugeosynclinal sediments, the pelitic rocks are generally $\mathrm{K}_{2} \mathrm{O}>\mathrm{Na}_{2} \mathrm{O}$ but psammitic rocks are $\mathrm{Na}_{2} \mathrm{O}>\mathrm{K}_{2} \mathrm{O}$ (Ishihara et al., 1985). Contribution of the sedimentary rocks on the granitoids of the Ryoke and southern Sanyo belts were proved by relatively high oxygen-isotopic ratios on the mineral and whole rock values on these granitoids (Honma and Sakai, 1976; Ishihara and Matsuhisa, 2001).

Among mafic components, $\mathrm{MgO}$ and $\mathrm{TiO}_{2}$ are enriched in the granitoids of the Sanin belt (Fig. 2A and Fig. 3B), reflecting Mg-rich compositions of the mafic silicates (Czamanske et al., 1981) and abundant titanite occurring as accessary mineral (e.g., 0.9 vol.\% in the Kawai mingling rock, Ishihara, 1971), yet no distinct difference observed on the total iron as $\mathrm{Fe}_{2} \mathrm{O}_{3}$ (Fig. 3C) and $\mathrm{MnO}$ (Fig. 3D). Minor element of $\mathrm{Zn}$ (Fig. 5B) is associated with these mafic rock-forming minerals, yet not reflecting on the regional zonal variations.

Both $\mathrm{Rb}$ (Fig. 4A) and $\mathrm{Pb}$ (Fig. 5A) contents increase with increasing $\mathrm{SiO}_{2}$ content, because the silica contents are positively correlated with the $\mathrm{K}_{2} \mathrm{O}$ contents, and $\mathrm{Rb}$ and $\mathrm{Pb}$ tend to replace 


\begin{tabular}{|llllll|}
\hline$\bullet$ & Sanin belt: & Shimane Prefecture & $\square$ & Sanyo belt: & Hiroshima city South \\
$\boldsymbol{\Delta}$ & Sanyo belt: & Miyoshi-Shobara cities & $\times$ & Ryoke belt: & Takanawa Peninsula \\
\hline & Sanyo belt: & Hiroshima city North & & & \\
\hline
\end{tabular}
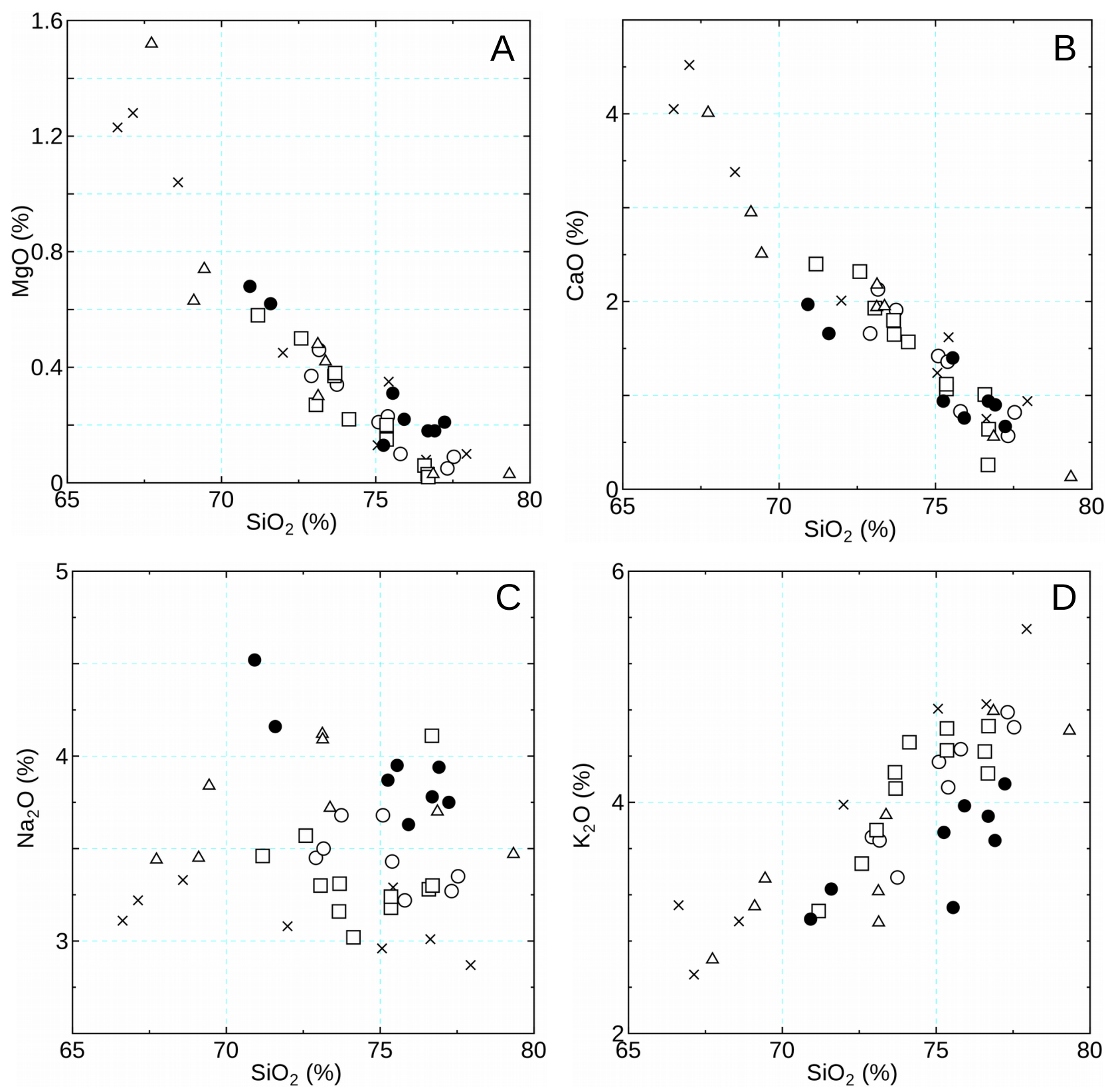

Fig. 2 Contents of $\mathrm{MgO}, \mathrm{CaO}, \mathrm{Na}_{2} \mathrm{O}$ and $\mathrm{K}_{2} \mathrm{O}$ plotted against $\mathrm{SiO}_{2}$ of the granitoids along the Hiroshima city transect. 


\begin{tabular}{|llllll|}
\hline$\bullet$ & Sanin belt: & Shimane Prefecture & $\square$ & Sanyo belt: & Hiroshima city South \\
$\Delta$ & Sanyo belt: & Miyoshi-Shobara cities & $\times$ & Ryoke belt: & Takanawa Peninsula \\
\hline & Sanyo belt: & Hiroshima city North & & & \\
\hline
\end{tabular}
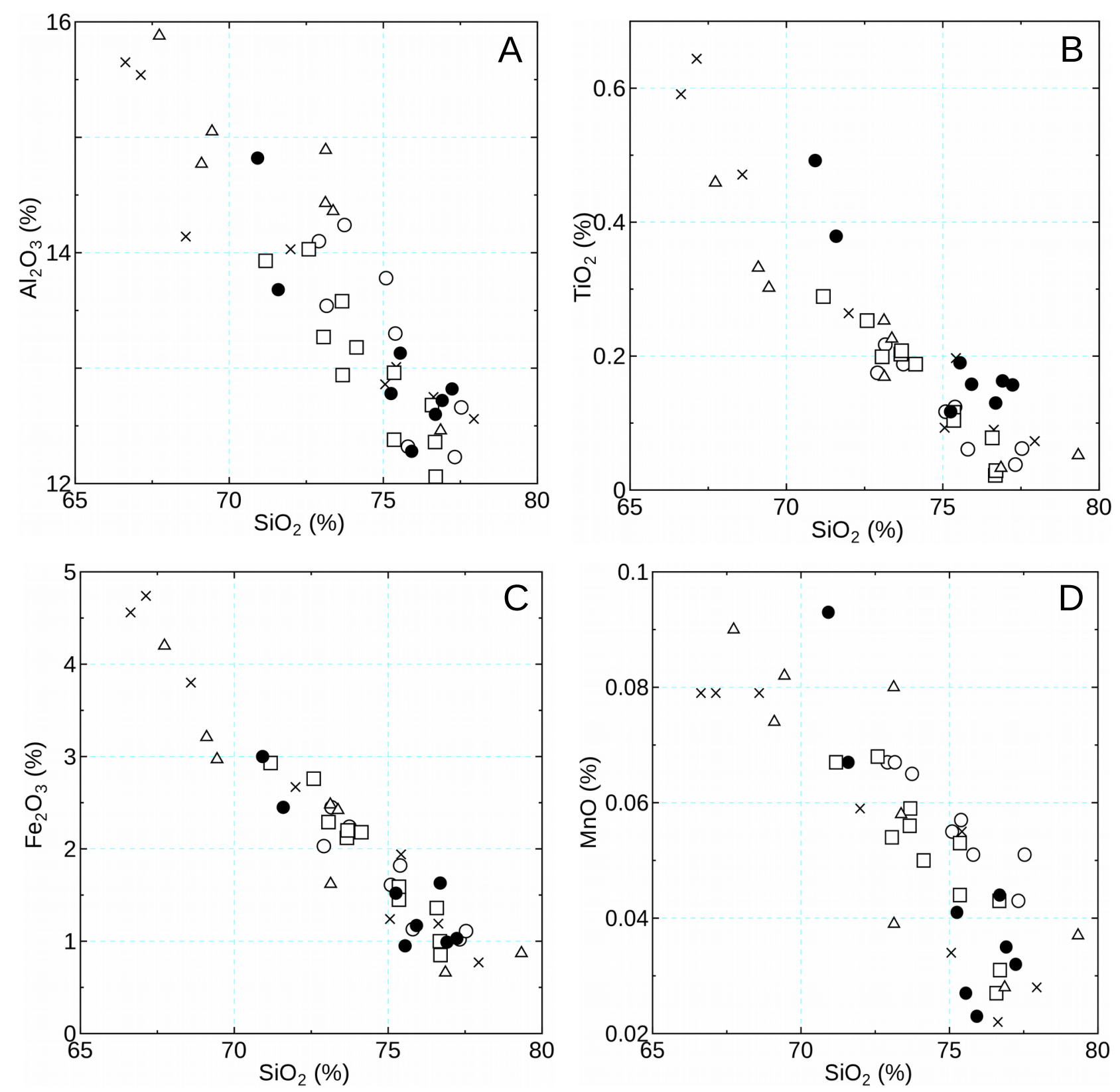

Fig. 3 Contents of $\mathrm{Al}_{2} \mathrm{O}_{3}, \mathrm{TiO}_{2}, \mathrm{Fe}_{2} \mathrm{O}_{3}$ and $\mathrm{MnO}$ plotted against $\mathrm{SiO}_{2}$ of the granitoids along the Hiroshima city transect. 

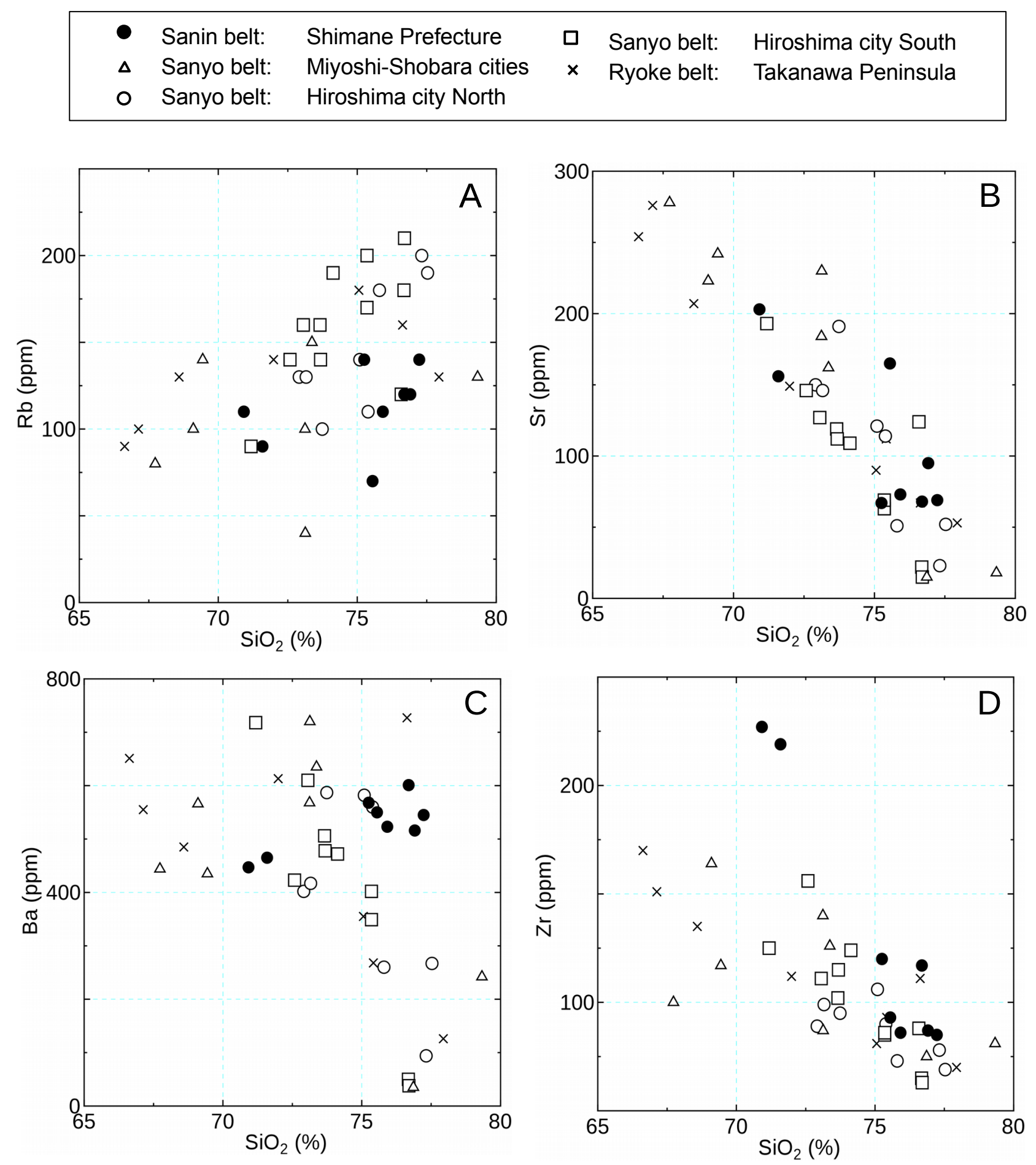

Fig. 4 Contents of $\mathrm{Rb}, \mathrm{Sr}, \mathrm{Ba}$ and $\mathrm{Zr}$ plotted against $\mathrm{SiO}_{2}$ of the granitoids along the Hiroshima city transect. 


\begin{tabular}{|llllll|}
\hline$\bullet$ & Sanin belt: & Shimane Prefecture & $\square$ & Sanyo belt: & Hiroshima city South \\
$\Delta$ & Sanyo belt: & Miyoshi-Shobara cities & $\times$ & Ryoke belt: & Takanawa Peninsula \\
\hline & Sanyo belt: & Hiroshima city North & & & \\
\hline
\end{tabular}
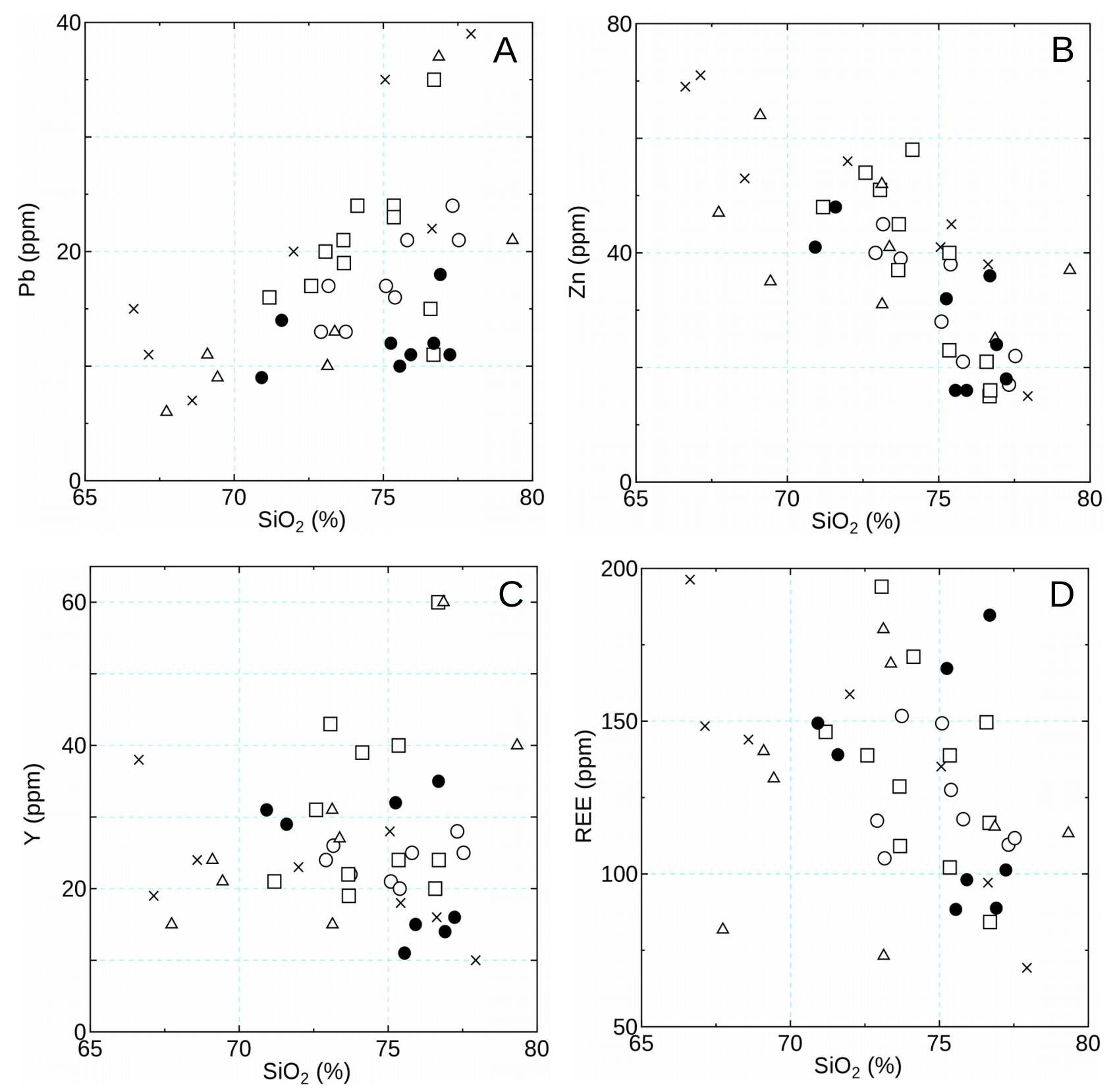

Fig. 5 Contents of $\mathrm{Pb}, \mathrm{Zn}, \mathrm{Y}$ and REE plotted against $\mathrm{SiO}_{2}$ of the granitoids along the Hiroshima city transect. 
K-position of the K-feldspar. However, the amounts are different in each zone, being low in the Sanin belt, but high in the Ryoke belt and the Sanyo belt of Hiroshima south. Enrichment of Rb and $\mathrm{Pb}$ in the granitoids of the Sanyo belt right next to the Ryoke belt has also been recognized at the Chubu transect, which are due to degree of magmatic fractionation (Ishihara and Terashima, 1977).

Sr contents are generally lower than $300 \mathrm{ppm}$ in the studied granitoids and go down to $15 \mathrm{ppm}$. The contents are positively correlated with $\mathrm{CaO}$ contents. $\mathrm{Y}$ contents range generally from 40 to $15 \mathrm{ppm}$ in the granodiorite and granite compositions, giving rise to low $\mathrm{Sr} / \mathrm{Y}$ ratio of $<1$ to 27 in the studied granitoids (Tables 1 to 5), which are non-adakitic character. However, adakitic rocks were reported toward the east and the west, such as the Kinki district of the Sanyo belt (e.g., Tamba Granitoids; Kiji et al., 2000) and Ryoke belt (Katsuragi Granitoids; Nishioka, 2008), also in the northern part of the Kyushu District (Izawa et al., 1990; Yada and Owada, 2003; Kamei, 2004). Ba may have the same trend as the $\mathrm{Sr}$ plotted, but the figure is somewhat erratic (Fig. 4C).

$\mathrm{Zr}$ contents are high in the granitoids of the Sanin belt (Fig. 4D). Zircon saturation temperatures of Watson and Harrison (1983), listed in Tables 1 to 5, however, are highest in the Ryoke zone $\left(753^{\circ} \mathrm{C}, \mathrm{n}=9\right)$ because granodiorite is much abundant here. Granitic rocks in the other zones, all in monzogranitic composition, have the average temperatures of $741-749^{\circ} \mathrm{C}$ as follows :

Sanin belt : $747^{\circ} \mathrm{C}(\mathrm{n}=9)$

Sanyo belt : Miyoshi-Shobara : $741^{\circ} \mathrm{C}(\mathrm{n}=7)$

Sanyo belt : Hiroshima north : $749^{\circ} \mathrm{C}(\mathrm{n}=8)$

Sanyo belt : Hiroshima south : $745^{\circ} \mathrm{C}(\mathrm{n}=11)$

Ryoke belt : Takanawa Peninsula : $753^{\circ} \mathrm{C}(\mathrm{n}=9), 744^{\circ} \mathrm{C}(\mathrm{n}=5$, granite only)

Alumina saturation index (A/CNK) was calculated and listed in Tables 1 to 5. It is above 1.0 in the monzogranitic composition, i.e., defined as peraluminous, but never exceeds 1.1, which is the value necessary to define as S-type granitoids. Thus, all the plutonic rocks studied belong to I type.

\section{Concluding remarks}

The late Cretaceous-Paleogene granitoids were studied to examine the N-S geochemical variations across the city of Hiroshima. The studied granitoids are most felsic part among the Japanese granitic terranes, being mostly monzogranitic, although the Ryoke granitoids are composed of both granodiorite and monzogranite. The magnetic susceptibility is the least in the Ryoke belt, and increases northwards, but typical magnetiteseries values appear in those of the Sanin belt, implying the oxygen fugacity of the granitic magmas increased northwards.

The initial Sr ratios decrease from 0.7082 of the Ryoke belt to 0.7050 of the Sanin belt (Shibata and Ishihara, 1979). The whole-rock oxygen isotopic ratios also decrease from 10.3-11.3 $\%$ on the Takanawa Peninsula, northward to $6-8 \%$ in the DaitoMinari area of the Sanin District (Ishihara and Matsuhisa, 2001). These observations indicate that older sedimentary and igneous rocks contained in the source rocks of the granitic magmas in the Ryoke and Sanyo belts, while only igneous source rocks were involved in those of the Sanin belt.

Among major chemistry, the $\mathrm{Na}_{2} \mathrm{O}$ contents are clearly high in the Sanin belt, and $\mathrm{K}_{2} \mathrm{O}$ contents tend to be enriched in the Ryoke belt. The $\mathrm{Na}_{2} \mathrm{O} / \mathrm{K}_{2} \mathrm{O}$ ratio, therefore, increases northwards that reflect the difference in the source rocks. High $\mathrm{Sr}$ granitoids and adakitic rocks (Martin et al., 2005; Moyen, 2009) were not found in the studied region, but reported in the northern Kyushu granitic region, and in the Kinki District of the Sanyo and Ryoke granitic belts (Kiji et al., 2000; Nishioka, 2008), which have been located toward west and east of our studied region.

\section{Acknowledgement}

The authors acknowledge greatly Dr. H. Matsuura of the Geological Survey of Japan, for his careful reviewing of the original manuscript and constructive comments, and also to Dr. Y. Takahashi for his useful advice.

\section{References}

Aoki, Y. and Hida, N. (1974) Geology and genesis of beryllium ore deposit, Mihara mine, Hiroshima Prefecture, Japan. Mining Geol., 24, 201-211 (in Japanese with English abstract).

Czamanske, G.K., Ishihara, S. and Atkins, S. A. (1981) Chemistry of rock-forming minerals of the Cretaceous-Paleogene batholith in southwestern Japan and implications for magma genesis. Jour. Geophy. Res., 86, no. B11, 10431-10469.

Hayashi, T. (1995) Geological petrological studies on the Hiroshima Granite in the Togouchi-Yuu-Takehara district, Southwest Japan. Bull. Fac. Sci. Educ., Hiroshima Univ., Part II, 17, 95-150.

Higashimoto, S. (1975) On the Hiroshima and the San-in granites of the $\mathrm{O}$-asa area, central Chugoku mountain-land. Bull. Geol. Surv. Japan, 26, 513-518 (in Japanese with English abstract).

Higashimoto, S., Matsuura, H., Mizuno, K. and Kawada, K. (1985) Geology of the Kure district. With Geological Sheet Map at 1:50,000, Geol. Surv. Japan, 93 p. (in Japanese with English abstract 6 p.). 
Hirokawa, O. (1965) Explanatory text of the geological map of Japan, Scale 1:50,000, Imabari-Seibu. Geol. Surv. Japan, 26 p. (in Japanese with English abstract 6 p.).

Honma, H. and Sakai, H. (1976) Zonal distribution of oxygen isotope ratios in the Hiroshima granite complex, Southwest Japan. Lithos, 3, 173-178.

Honma, H., Kagami, H. and Okamoto, Y. (1983) Oxygen and strontium isotopic ratios of the Ryoke and Hiroshima-type granitoids at Takanawa Peninsula, Shikoku. Magma, no. 67, 115-121 (in Japanese).

Iida, K., Iwamori, K., Orihashi, Y., Park, T., Jwa, Y. J., Kwon, S. T., Danhara, T. and Iwano, H. (2015) Tectonic reconstruction of the batholith formation based on the spatiotemporal distribution of Cretaceous-Paleogene granitic rocks in southwestern Japan. Island Arc, 24, 205-220.

Ishihara, S. (1971) Modal and chemical composition of the granitic rocks related to the major molybdenum and tungsten deposits in the Inner Zone of Southwest Japan. Jour. Geol. Soc. Japan, 77, 441-452.

Ishihara, S. (1979) Lateral variation of magnetic susceptibility of the Japanese granitoids. Jour. Geol. Soc. Japan, 85, 509-523.

Ishihara, S. and Matsuhisa, Y. (2001) Oxygen isotopic constraints on the geneses of the Cretaceous-Paleogene granitoids in the Inner Zone of Southwest Japan. Bull. Geol. Surv. Japan, 53, 421-438.

Ishihara, S. and Moriyama, T. (2016) Apatite composition of representative magnetite-series and ilmenite-series granitoids in Japan. Resource Geol., 66, 55-62.

Ishihara, S. and Tani, K. (2004) Magma mingling/mixing vs. magmatic fractionation: Geneses of the Shirakawa Momineralized granitoids, central Japan. Resource Geol., 54, 373-382.

Ishihara, S. and Tani, K. (2013) Zircon age of granitoids hosting molybdenie-quartz vein deposits in the central Sanin Belt, Southwest Japan. Shigenchisisu (Resource Geology), 63, 11-14 (in Japanese with English abstract).

Ishihara, S. and Terashima, S. (1977) Chemical variation of the Cretaceous granitoids across southwestern Japan. -Shirakawa-Toki-Ryoke transect-. Jour. Geol. Soc. Japan, 83, $1-18$.

Ishihara, S., Komura, K. and Murakami, T. (1969) Source rocks of Miocene bedded-type uraniferous deposits in northern Miyoshi District and genesis of uranium anomalies at Myoga, Shobara city, Hiroshima Prefecture, Japan. Bull. Geol. Surv. Japan, 20, 161-172 (in Japanese with English abstract).

Ishihara, S., Teraoka, Y., Terashima, S. and Sakamaki, Y. (1985) Chemical variation of Paleozoic-Cenozoic sandstone and shale across the western Shikoku district, Southwest Japan. Bull. Geol. Surv. Japan, 36, 85-102.

Izawa, E., Karakida, Y., Shimada, N. and Takahashi, M. (1990) Is the high-Sr granitoid indicative for thick continental crust? Earth Monthly, 12, 436-439 (in Japanese).

Kamei, A. (2004) An adakitic pluton on Kyushu Island, southwest Japan arc. Jour. Asian Earth Sci., 24, 43-58.

Kawano, Y. and Ueda, Y. (1966) K-A dating on the igneous rocks in Japan (V). -Granitic rocks in southwestern Japan-. Jour. Miner. Petrol. Sci., 56, 191-211 (in Japanese with English abstract).

Kiji, M., Ozawa, H. and Murata, M. (2000) Cretaceous adakitic Tamba granitoids in northern Kyoto, San' yo belt, Southwest Japan. Jour. Mineral. Petrol. Sci., 29, 136-149 (in Japanese with English abstract).

Martin, H., Smithies, R.H., Rapp, R., Moyen, J.-F. and Champion, D. (2005) An overview of adakite, tonalite-trondhjemitegranodiorite (TTG), and sanukitoid: relationships and some implications for crustal evolution. Lithos, 79, 1-24.

Matsuura, H. (1989) Radiometric ages of Late Cretaceous to Paleogene igneous rocks in the central San-in region, Southwest Japan. Bull. Geol. Surv. Japan, 40, 479-495 (in Japanese with English abstract).

Matsuura, H. (1990) Geology of the Akana district. With Geological Sheet Map at 1: 50,000, 73 p. (in Japanese with English abstract 5 p.).

Matsuura, H. (1998) K-Ar ages of the Mimuro and Mitsumori Granites, Chugoku district, Southwest Japan. Jour. Miner. Petrol. Sci., 93, 182-185 (in Japanese with English abstract).

Minagawa, T., Momoi, H. and Noto, S. (1978) Rare element minerals from pegmatites in the Ryoke Belt, western Shikoku, Japan. Mem. Ehime Univ. Sci. Ser. D (Earth Sci.), VIII, 3-11 (in Japanese with English abstract).

Minagawa, T., Funakoshi, N. and Morioka, H. (2001) Chemical properties of allanite from the Ryoke and Hiroshima granite pegmatites in Shikoku, Japan. Mem. Fac. Sci., Ehime Univ., 7, 1-13 (in Japanese with English abstract).

Miyahisa, M. and Hiraoka, T. (1970) Geological relations of granitic rocks bodies in the Ryoke belt, western Shikoku, Japan. Mem. Ehime Univ. Sci. Ser. D, VI, no. 3, 21-34 (in Japanese with English abstract).

Moyen, J.-F. (2009) High Sr/Y and La/Yb ratios: The meaning of "adakitic signature". Lithos, 112, 556-574.

Murakami, N. (1959) Metasomatic syenites occurring in granitic rocks of southwestern Japan. Sci. Rept. Yamaguchi Univ. 10, 73-90.

Nishioka, Y. (2008) Large-scale Adakitic igneous activity of Late Cretaceous found to the Katsuragi Tonalite in the Ryoke Belt. Abstract of the $115^{\text {th }}$ annual meeting of the 
Geological Society of Japan, 131.

Ochi, S. (1982) The Ryoke granitic rocks in the Takanawa Peninsula, Shikoku, Japan. Jour. Geol. Soc. Japan, 88, 511-522 (in Japanese with English abstract).

Okamura, Y. (1967) Ryoke granitic rocks of the western part of Setonaikai, Southwest Japan. Professor Hidekata Shibata Memorial Volume, 53-62 (in Japanese with English abstract)

Rezanov, A. I., Kagami, H. and Iizumi, S. (1994) Rb-Sr isochron ages of Cretaceous-Paleogene granitoid rocks in the central part of the Chugoku district, Southwest Japan. Jour. Geol. Soc. Japan, 100, 651-657.

Sato, K., Ishihara, S. and Shibata, K. (1992) Granitoid map of Japan; 1992. Scale 1:3,000,000. In Geological Atlas of Japan, $2^{\text {nd }}$ ed., Geol. Surv. Japan.

Sato, K., Minakawa, T., Kato, T., Maki, K., Iwano, H., Hirata, T., Hayashi, S. and Suzuki, K. (2014) Behavior of rare elements in Late Cretaceous pegmatites from the Setouchi Province, Inner Zone of southwest Japan. Jour. Miner. Petrol. Sci., 109, 28-33.

Shibata, K. and Ishihara, S. (1974) K-Ar ages of biotites across the central part of the Hiroshima Granite. Jour. Geol. Soc. Japan, 80, 431-433 (in Japanese with English abstract).

Shibata, K. and Ishihara, S. (1979) Initial ${ }^{87} \mathrm{Sr} /{ }^{86} \mathrm{Sr}$ ratios of plutonic rocks from Japan. Contrib. Mineral. Petrol., 70, 381-390.

Takagi, T. and Mizuno, K. (1999) Geology of the Kaitaichi district. With geological sheet map at 1:50,000. Geol. Surv. Japan, 49 p. (in Japanese with English abstract 4 p.).
Takagi, T., Kagami, H. and Iizumi, S. (1989) Petrography and geochemistry of two contrasting I-type granites, the Mitsumori and Ikuridani Granites, San' in belt, Southwest Japan. Jour. Geol. Soc. Japan, 95, 905-918.

Takahashi, Y. (1991) Geology of the Hiroshima District. With Geological Sheet map at 1:50,000. Geol. Surv. Japan, 41 p. (in Japanese with English abstract 3 p.)

Takahashi, Y. (1993) Hiroshima Granite-Enormous vertically zoned pluton. Jour. Miner. Petrol. Sci., 88, 20-27 (in Japanese with English abstract 4 p.).

Takahashi, Y., Makimoto, H., Wakita, K. and Sakai, A. (1989) Geology of the Tsuda district. With Geological Sheet Map at 1:50,000, 56 p. (in Japanese with English abstract).

Tani, K., Horie, K., Dunkley, D. and Ishihara, S. (2014) Pulsed granitic crust formation revealed by comprehensive SHRIMP zircon dating of the SW Japan granitoids. Abstract of Japan Geosci. Union Meeting. Yokohama, 2014.

Watson, E. B. and Harrison, T. M. (1983) Zircon saturation revisited: temperature and composition effects in a variety of crustal magma types. Earth Planet. Sci. Let., 64, 295-304.

Yada, J. and Owada, M. (2003) Genetic relationship between the Cretaceous high-Sr tonalite (Itoshima mass) and trodhjemite (Fukae mass) in the central part of Saga Prefecture, northwest Kyushu: Implication for magmatic differentiation. Jour. Geol. Soc. Japan, 109, 518-532 (in Japanese with English abstract).

Recieved December 8, 2015

Accepted May 9, 2016 
Appendix 1 Locality and magnetic susceptibility of the analyzed specimens.

\begin{tabular}{|c|c|c|c|}
\hline Filing \& Sample nos. & Locality & Rock name & $\mathrm{x}$ value $\left(10^{-6} \mathrm{Am}^{2} / \mathrm{kg}\right)$ \\
\hline & Ryoke belt: Takanawa Peninsula, Ehime Prefecture & & \\
\hline I. $75 \mathrm{MY} 10$ & Imabari-shi, Namikata-cho, Mategata & Fine-grained gabbroid & $x=30$ \\
\hline 2. $75 \mathrm{MY} 15$ & ditto, Daikaku-bana & Medium diorite & $x=19$ \\
\hline 3. $75 \mathrm{MY} 14$ & ditto, Morigami & Very coarse syenite & $x=12$ \\
\hline 4. $75 \mathrm{MY} 20$ & Matsuyama-shi, Kikuma-cho, Shimojo-Ogawa & Very coarse granodiorite, foliated & $x=15$ \\
\hline 5. $75 \mathrm{MY} 6$ & ditto, Tanojiri-Iwadouji coast & Very coarse granodiorite, foliated & $x=16$ \\
\hline 6. $75 \mathrm{MY} 21$ & Ochi-gun, Tamakawa-cho, Shimokiji & Very coarse granodiorite, foliated & $x=18$ \\
\hline 7. $75 \mathrm{MY} 4$ & Matsuyama-shi, Takahama coast & Medium, bt granite & $x=19$ \\
\hline 8. $75 \mathrm{MY} 13$ & Imabari-shi, Namikata-cho, Shiraiwa pegmatite mine & Medium, bt granite & $x=20$ \\
\hline 9. $75 \mathrm{MY} 2$ & Matsuyama-shi east, Shukunono & Coarse, bt granite & $x=14$ \\
\hline 10. $75 \mathrm{MY} 5$ & Matsuyama-shi, Hojyo, coast at Kuriizaka & Aplitic granite & $x=15$ \\
\hline \multirow[t]{2}{*}{ 11. $75 \mathrm{MY} 1$} & Matsuyama-shi far east, Fujinono & Fine, bt leucogranite & $x=13$ \\
\hline & Sanyo belt: Hiroshima city south, Hiroshima Prefecture & & \\
\hline 12. OSM01 & Kure-shi, Kurahashi-jima, Osame & Medium bt granite & $x=18$ \\
\hline 13. $76 \mathrm{H} 156$ & Kure shi, Hiro-machi & Coarse, hb-bt granite & $x=20$ \\
\hline 14. $76 \mathrm{H} 153$ & Kure Line, Koyaura station & Ditto, pink Kf granite & $x=96$ \\
\hline 15. $76 \mathrm{H} 152$ & Kure Line, $2.3 \mathrm{~km}$ to Saka station & Very coarse, hb-bt granite & $x=22$ \\
\hline 16. 410072 & Aki-gun, Fuchu-cho, road to Mt. Gosaso & Fine bt granite, pink Kf & $x=57$ \\
\hline 17. 410074 & Aki-gun, Fuchu-cho, road to Mt. Gosaso & Fine bt granite, very fresh & $x=24$ \\
\hline 18. $76 \mathrm{H} 151$ & Hiroshima-shi, Iwahana, old quarry & Fine aplitic granite & $x=19$ \\
\hline 19. $76 \mathrm{H} 161$ & Higashi Hiroshima-shi, Shiwa-higashi & Coarse hb-bt granite & $x=99$ \\
\hline 20. $76 \mathrm{H} 158$ & Higashi Hiroshima-shi, Akitsu tunnel & Very coarse bt granite & $x=58$ \\
\hline 21. $73 \mathrm{H} 77$ & Hiroshima-shi, Saiki-ku, Itsukaichi-cho, Jiro-Goro-taki, 1 km from electric power stn. & Fine, pink Kf granite & $x=18$ \\
\hline \multirow[t]{2}{*}{ 22. $73 \mathrm{H} 98$} & Hiroshima-shi, Saiki-ku, Saiki-cho, Sakai-Sekizai & Fine bt granite & $x=77$ \\
\hline & Sanyo belt: Hiroshima city north, Hiroshima Prefecture & & \\
\hline 23. $73 \mathrm{H} 72$ & Yamagata-gun, Kitahiroshima-cho, Kokitsugi & Fine ol-px gabbro & $x=731$ \\
\hline 24. $73 \mathrm{H} 89$ & ditto. Honji-Urihara, Nakano-Sekizai & Medium diorite, "Aomikage" & $x=489$ \\
\hline 25. $73 \mathrm{H} 93$ & Hiroshima-shi, Asakita-ku, Kabe-cho, Nabara-dum waste & Coarse hb-bt granite & $x=75$ \\
\hline 26. $73 \mathrm{H} 86$ & Yamagata-gun, Kitahiroshima-cho, Oasa, Ikadatsu & Medium aplitic granite & $x=132$ \\
\hline 27. $73 \mathrm{H} 67$ & ditto, Kitahiroshima-cho, Kawato & Fine bt granite, marginal phase & $x=25$ \\
\hline 28. $73 \mathrm{H} 68$ & ditto, Kitahiroshima-cho, Choja & Coarse bt granite & $x=93$ \\
\hline 29. $73 \mathrm{H} 83 \mathrm{~A}$ & ditto, ditto, Oasa, Yokogawa & Medium bt granite & $x=140$ \\
\hline 30. $73 \mathrm{H} 83 \mathrm{~B}$ & The same locality as $73 \mathrm{H} 83 \mathrm{~A}$ & Fine aplitic granite & $x=85$ \\
\hline 31. $73 \mathrm{H} 88$ & Yamagata-gun, Kitahiroshima-cho, Oasa, Kami Narutaki & Fine bt granite & $x=71$ \\
\hline \multirow[t]{2}{*}{ 32. $73 \mathrm{H} 82$} & ditto, ditto, Toyohira, Shirohara & Aplitic granite & $x=137$ \\
\hline & Sanyo belt: Miyoshi-Shobara cities, Hiroshima Prefecture & & \\
\hline 33. $74 \mathrm{H} 119$ & Miyoshi-shi, Sakugi-cho, Karako & $\mathrm{Hb}$-bearing bt granite & $x=160$ \\
\hline 34. $67 S 15$ & Shobara-shi, Kuchiwa-cho, Miyauchi & Fine px-hb qz gabbro & $x=1,166$ \\
\hline 35. $67 \mathrm{~S} 31$ & ditto, Kimita-cho, Terahara & Medium hb-bt granodiorite & $x=792$ \\
\hline 36. $67 \mathrm{~S} 26$ & ditto, Kimita-cho, Morihara & Fine granite porphyry & $x=69$ \\
\hline $37.67 \$ 39$ & ditto, Funo-cho, Nakamura & Medium hb-bt granodiorite & $x=387$ \\
\hline 38. $67 \mathrm{~S} 21$ & ditto, Kuchiwa-cho, $700 \mathrm{~m} \mathrm{~W}$ of Yoshiki & Medium hb-bt granodiorite & $x=283$ \\
\hline 39. $67 \mathrm{~S} 25$ & ditto, Kuchiwa-cho, Ashihara & Medium hb-bt granodiorite & $x=17$ \\
\hline 40. $67 \mathrm{~S} 32$ & ditto, Kimita-cho, Nakanohara & Fine, bt granite & $x=19$ \\
\hline \multirow[t]{2}{*}{ 41. $67 \mathrm{~S} 27$} & ditto, Kimita-cho, Fujikane N, Irigimi body & Fine porphyritic aplite & $x=14$ \\
\hline & Sanin belt: Shimane Pref. and Northernmost Hiroshima Prefecture & & \\
\hline 42. $73 \mathrm{H} 51$ & Unnan-shi, Kakeya-cho, Nakatani & Bt-hb granodiorite & $x=698$ \\
\hline 43. $73 \mathrm{H} 60$ & Ochi-gun, Misato-cho, Tunnel waste & Medium bt granite & $x=235$ \\
\hline 44. $73 \mathrm{H} 61$ & Ochi-gun, Misato-cho, Oura & Medium bt granite & $x=160$ \\
\hline 45. $73 \mathrm{H} 64$ & Ochi-gun, Onan-cho, near H63 & Fine bt granite & $x=85$ \\
\hline 46. $73 \mathrm{H} 63$ & Ochi-gun, Onan-cho, below bridge & Aplitic granite & $x=215$ \\
\hline 47. $73 \mathrm{H} 62$ & ditto, Onan-cho, Asuna north $1.2 \mathrm{~km}$ & Aplitic granite & $x=362$ \\
\hline 48. $73 \mathrm{H} 65$ & Ochi-gun, Onan-cho, Danbara & Green bt granite & $x=642$ \\
\hline 49. $73 \mathrm{H} 87$ & Ochi-gun, Onan-cho, Kobayashi & Fine aplitic granite & $x=193$ \\
\hline 50. $73 \mathrm{H} 66$ & Yamagata-gun, Kita-Hiroshima-cho, Oasa north & Fine porphyritic granite & $x=316$ \\
\hline
\end{tabular}

bt: biotite, hb: hornblende, Kf: alkali feldspar, ol: olivine, px: pyroxene 


\title{
西南日本内帯, 広島付近を横断する後期白亜紀一古第三紀花崗岩類の地球化学的性質の南北変化
}

\author{
石原舜三・大野哲二 \\ 要 旨
}

標記地域の花崗岩類分布域は南から領家帯・山陽帯・山院帯に分けられる. 領家帯では花崗岩のほか花崗閃緑岩が分布 するが，山陽帯と山陰帯では少量の斑机い岩-閃緑岩を伴うものの主体は花崗岩である. 全岩帯磁率は山院帯で最も高く, 南方に低くチタン鉄鉱系の值となり, 領家帯で最少となる. ジルコン U-Pb 年代は, 領家帯が最も古く $97.8 \sim 95.3 \mathrm{Ma}$, 山 陽帯が 92.3 85.6 Ma, 山陰帯が 39.8 33.5 Maである. 化学組成上は $\mathrm{Na}_{2} \mathrm{O} / \mathrm{K}_{2} \mathrm{O}$ が山陰帯の花崗岩類で最も大きく, 領家 帯の岩石で最も小さい. これは水成岩起源で同比が大きく堆積岩起源で同比が小さい起源物質の性質を反映しているもの と思われる. アルミナ飽和指数は 1.0 は超えるが, 1.1 を超える $\mathrm{S}$ タイプは存在しない. カリ長石の $\mathrm{K}$ を置換する $\mathrm{Rb}$ とb は山陰帯で最も乏しく, 領家帯とその北縁の山陽帯で富んでいる. この傾向は ${ }^{18} \mathrm{O}$ の傾向と同様であって, そのマグマ の生成に堆積岩地殼物質が関与したことを示している. 